University of Nebraska - Lincoln

DigitalCommons@University of Nebraska - Lincoln

USGS Northern Prairie Wildlife Research Center

US Geological Survey

2008

\title{
Restoration of Mangrove Plantations and Colonisation by Native Species in Leizhou Bay, South China
}

\author{
Hai Ren \\ Heshan National Field Research Station of Forest Ecosystem, South China Botanical Garden, The Chinese \\ Academy of Sciences, Guangzhou 510650, China \\ Shuguang Jian \\ Heshan National Field Research Station of Forest Ecosystem, South China Botanical Garden, The Chinese \\ Academy of Sciences, Guangzhou 510650, China \\ Hongfang Lu \\ Heshan National Field Research Station of Forest Ecosystem, South China Botanical Garden, The Chinese \\ Academy of Sciences, Guangzhou 510650, China \\ Qianmei Zhang \\ Heshan National Field Research Station of Forest Ecosystem, South China Botanical Garden, The Chinese \\ Academy of Sciences, Guangzhou 510650, China \\ Weijun Shen \\ Heshan National Field Research Station of Forest Ecosystem, South China Botanical Garden, The Chinese \\ Academy of Sciences, Guangzhou 510650, China \\ See next page for additional authors \\ Follow this and additional works at: https://digitalcommons.unl.edu/usgsnpwrc \\ Part of the Other International and Area Studies Commons
}

Ren, Hai; Jian, Shuguang; Lu, Hongfang; Zhang, Qianmei; Shen, Weijun; Han, Weidong; Yin, Zuoyun; and Guo, Qinfeng, "Restoration of Mangrove Plantations and Colonisation by Native Species in Leizhou Bay, South China" (2008). USGS Northern Prairie Wildlife Research Center. 15.

https://digitalcommons.unl.edu/usgsnpwrc/15

This Article is brought to you for free and open access by the US Geological Survey at DigitalCommons@University of Nebraska - Lincoln. It has been accepted for inclusion in USGS Northern Prairie Wildlife Research Center by an authorized administrator of DigitalCommons@University of Nebraska - Lincoln. 
Authors

Hai Ren, Shuguang Jian, Hongfang Lu, Qianmei Zhang, Weijun Shen, Weidong Han, Zuoyun Yin, and Qinfeng Guo 
Hai Ren · Shuguang Jian $\cdot$ Hongfang Lu Qianmei Zhang - Weijun Shen · Weidong Han Zuoyun Yin - Qinfeng Guo

\section{Restoration of mangrove plantations and colonisation by native species in Leizhou bay, South China}

Received: 12 March 2007/ Accepted: 10 May 2007/Published online: 27 June 2007

\begin{abstract}
To examine the natural colonisation of native mangrove species into remediated exotic mangrove stands in Leizhou Bay, South China, we compared soil physical-chemical properties, community structure and recruitments of barren mangrove areas, native mangrove species plantations, and exotic mangrove species-Sonneratia apetala Buch.Ham - between plantations and natural forest. We found that severely degraded mangrove stands could not regenerate naturally without human intervention due to severely altered local environments, whereas some native species had been recruited into the 4-10 year $S$. apetala plantations. In the first 10 years, the exotic species $S$. apetala grew better than native species such as Rhizophora stylosa Griff and Kandelia candel (Linn.) Druce. The mangrove plantation gradually affected soil physical and chemical properties during its recovery. The exotic $S$. apetala was more competitive than native species and its plantation was able to restore soil organic matter in about 14 years. Thus, $S$. apetala can be considered as a pioneer species to improve degraded habitats to facilitate recolonisation by native mangrove species. However, removal to control proliferation may be needed at late stages to facili-
\end{abstract}

H. Ren $(\bowtie) \cdot$ S. Jian $\cdot$ H. Lu $\cdot$ Q. Zhang $\cdot$ W. Shen $\cdot$ Z. Yin Heshan National Field Research Station of Forest Ecosystem, South China Botanical Garden, The Chinese Academy of Sciences, Guangzhou 510650, China

E-mail: renhai@scib.ac.cn

Tel.: + 86-20-37252916

Fax: + 86-20-37252916

W. Han

Guangdong Ocean University, Zhanjiang,

524088 Guangdong, China

Q. Guo

Northern Prairie WRC, US Geological Survey,

Jamestown, ND 58401, USA

Q. Guo

Southern Research Station, USDA, Asheville,

NC 28804, USA tate growth of native species. To ensure sustainability of mangroves in South China, the existing mangrove wetlands must be managed as an ecosystem, with long-term scientific monitoring program in place.

Keywords Competitive exclusion - Mangrove ·

Ecosystem restoration - Invasive species .

Sonneratia apetala

\section{Introduction}

Woody mangrove plants are well known for their welldeveloped morphological and physiological adaptations to their environmental conditions. Mangrove species grow at the interface between land and sea in tropical and sub-tropical regions with high salinity, brackish waters, and muddy, anaerobic soils, and play a very important role in the ecosystem processes of coastal areas. Mangroves create unique ecological environments that host rich assemblages of species, and also protect and stabilise coastlines, enrich coastal waters, yield commercial forest products, and support coastal fisheries (Snedaker 1984). However, accumulating evidence shows that mangrove species are particularly sensitive to human disturbances (Kovacs 1999; Lugo 1999; Zedler 2000; Kathiresan and Bingham 2001; Macintosh et al. 2002). In the past several decades, habitat destruction through human encroachment has been the primary cause of mangrove loss. Diversion of freshwater for irrigation and land reclamation have destroyed extensive mangrove forests, and heavy historical and continuing exploitation has severely damaged the remaining mangrove habitats. Early mangrove management has focussed on timber production and fuel wood, and mangroves have been managed for cultivation of fish, shrimp, and ecotourism. Because of this, conservation of remaining mangrove, and restoration of the most extensively degraded mangrove, has become a growing concern for ecologists, policy makers, and the general public (FAO 1994; Field 1999; Ellison 2000). 
Field (1999) and Ellison (2000) have reviewed and summarised many mangrove remediation/restoration projects. Among the restoration projects, silviculture is the principal practice. Coastal stabilisation and environmental mitigation or remediation have often been the objectives (Lewis 2005). Many restored mangrove forests resemble forest plantations rather than truly integrated or natural mangrove ecosystems. These plantations could be used as a first step toward mangrove remediation (Ellison 2000). Along with the relative reduction of sea level and the physical and chemical amendment of the soils, the mangrove community succession is gradual and progressive, and species replacement is orderly and predictable, from the simple pioneer stage through to the final stage (Zedler 2000). Where degraded mangrove systems are revegetated, continued monitoring and thorough assessment are needed to help understanding the recovery processes. This knowledge will help developing strategies to promote better remediation of degraded mangrove. However, so far little has been done to monitor and assess the early development and growth of planted stands, especially when exotic species are planted and re-colonisation by native mangrove species occurs.

'Guangdong province in China has important mangrove habitats, harbouring about $50 \%$ of Chinese mangrove (Lin 1999), over $80 \%$ of which are in the Leizhou Peninsula (Li 2003). The destruction of mangrove habitats has been caused by continual deforestation, fish/ shrimp-pond building, and the extension of urban areas. The total area of mangrove ecosystem in Leizhou Peninsula decreased from about 14,027 ha to about 7,305.8 ha (including the 2,378.3 ha successfully remediated during 1991-2000) from 1956 to 2001. According to the State Forestry Administration of China, 2,000 ha mangrove will be planted per year during 2003-2007, with Leizhou Peninsula as the key area. Three classical remediation methods (natural remediation, indigenous species planting and exotic species introducing of mangrove) have been practised in the Leizhou Peninsula during the past 10 years (Han et al. 2003; Lin and Liu 2003).

The exotic mangrove species Sonneratia apetala Buch.Ham, was introduced to China in 1993. In this short period it has spread to Hainan, Guangdong, Guangxi, and Fujian provinces. More than 50 papers on $S$. apetala Buch.Ham plantation ecosystems were published between 1995 and 2005 (Lin et al. 2006). These reports described the morphology, geographical distribution, biological characteristics and adaptability of ecological factors. Some reported the ecological effects of $S$. apetala Buch.Ham plantation; those results showed that the soil type changes, the $\mathrm{pH}$ of the soil is reduced, and nitrogen, phosphorus, potassium and salt are increased. During the course of community forming, the biodiversity at first decreases and then increases (Zan et al. 2001a, b; Wang et al. 2002; Liao et al. 2004).

Here we compare the soil properties, community structure and recruitment of barren mangrove areas, native species plantations, and exotic mangrove species between planted and natural mangrove forests. In particular, we evaluate the growth of the exotic mangrove species $S$. apetala, and the re-colonisation of nonplanted native mangrove species.

\section{Methods}

The study area is situated on the Leizhou Bay coast, about $20 \mathrm{~km}$ from Leizhou City $\left(109^{\circ} 03^{\prime} \mathrm{E}, 20^{\circ} 30^{\prime} \mathrm{N}\right)$, Guangdong, South China (Fig. 1). The annual average temperature is $22.9^{\circ} \mathrm{C}\left(28.4^{\circ} \mathrm{C}\right.$ in July and $15.5^{\circ} \mathrm{C}$ in January) and the annual precipitation is $1,711 \mathrm{~mm}$ (about $73 \%$ in the rainy season, April-October, and 27\% in the dry season). The soil is mangrove acid soil with three typical layers $(0-10 \mathrm{~cm}$ : black, with organic matter, 10-40 cm: grey, and $>40 \mathrm{~cm}$ : yellow or mixed colour). The $\mathrm{pH}$ value for top soils is 6.9 (Han et al. 2001).

A survey in 2005 showed that there were a total of 1,606.9 ha mangrove area in Leizhou Bay but only 106.8 ha remain undisturbed. In total, 16 plant species of mangrove are found in the bay. The area of mangroves in the bay had declined by 1,675.6 ha during the period 1980-2005. On the whole, the mangrove area in the bay has decreased markedly, due mainly to its transformation to aquaculture, which has profoundly affected the development of the local society and economy. The mudflats and mangrove areas of Leizhou Peninsula were listed as key sites for artificial ecological remediation in the 1990s, and local coastal governments have taken effective planting initiatives for native species such as Kandelia candel and Avicennia marina (Forsk.) Vierh. Besides native species, S. apetala, a native of Bengal, was successfully introduced into Leizhou Bay in 1993. It was first introduced into Dongzhaigang mangrove Nature Reserve of Hainan in 1985, then into Leizhou Bay, where it grew well (Li et al. 1998; Wu et al. 2000; Chen et al. 2004; Liao et al. 2005; Lin et al. 2006).

Extensive native mangroves historically covered the area. However, due to human disturbances, only small patches of natural stands remain. Within the study area, a freshwater channel passes through the edge of the woodland and provides year-round fresh water from the drainage in a sea-dyke. Geomorphologically, the site is also at the landward side of the intertide. Regular tides affect the stand, and the ground surface is about $1.5 \mathrm{~m}$ under water at high tide, and $0.6-1.2 \mathrm{~m}$ above water at low tide.

The quadrats of natural mangrove forest, barren site, native species mangrove plantation, and 4-, 5-, 8- and 10-year exotic species-S. apetala - plantations, were placed around the estuary. The barren and natural forest sites were treated as controls due to the similarity of environmental conditions, close distance and site history. The native species mangrove plantation was established in 1993. Seedlings of Rhizophora stylosa and $K$. candel were separated to individual plants in each block along a transect. The space between planted seedlings was $2 \mathrm{~m}$, giving 2,500 individuals/ha. The plants did not grow well and about $30 \%$ individuals died 

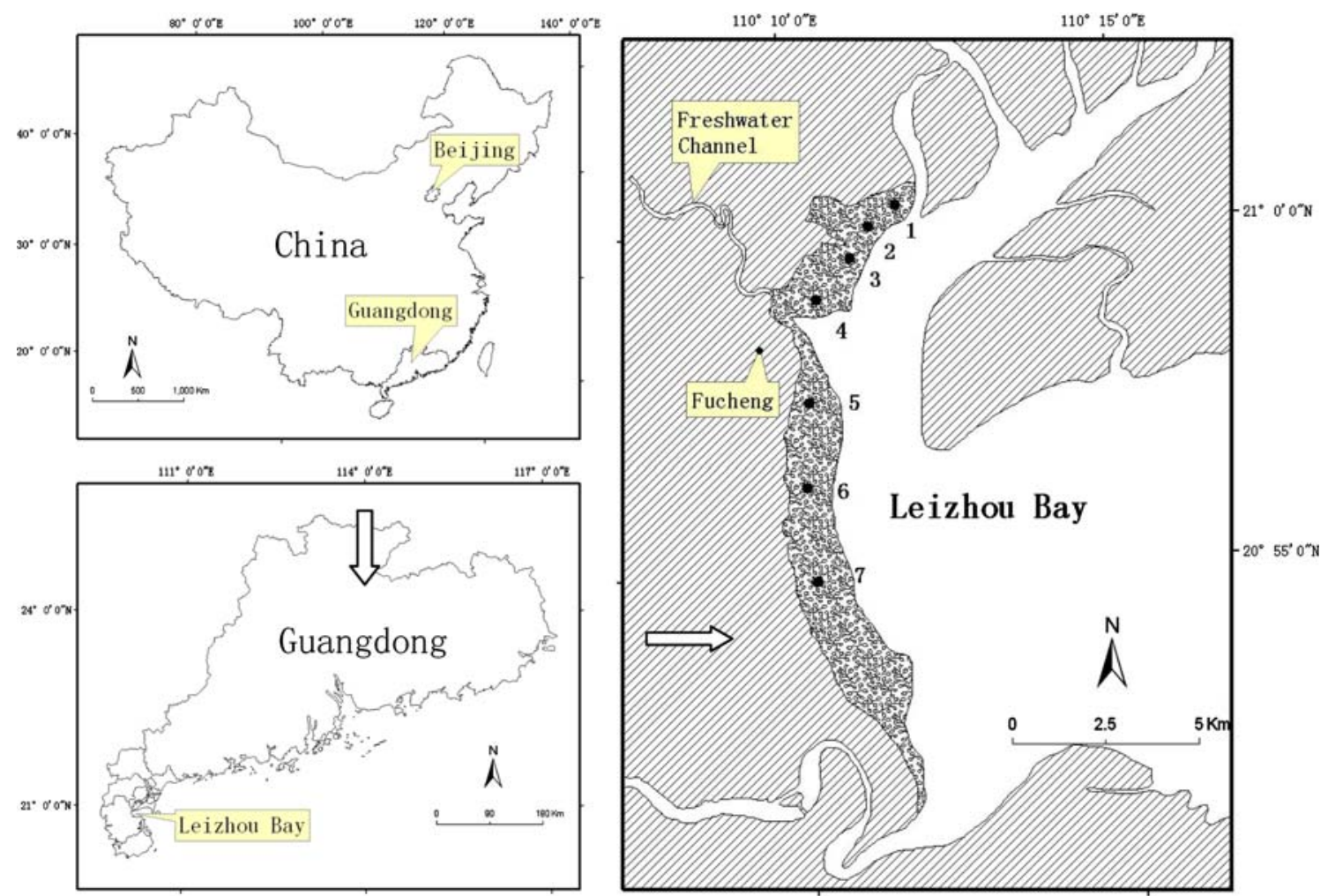

Fig. 1 Locations of the study sites in Leizhou Bay, Guangdong, South China. The numbers represent different ages of plantation: 1 5 -year plantation, 2 natural mangrove forest, 3 barren sites, 4

after several months. Plantations of $S$. apetala (seedlings) were established in 1995 (10-year), 1997 (8-year), 2000 (5-year), and 2001 (4-year). The space between planted seedlings was $2 \mathrm{~m}$, again giving 2,500 individuals/ha. Most individuals survived and grew well. The natural forest sites were small patches of secondary natural stands with little human disturbance. The barren site was kept for natural remediation after the mangrove was cleared out 20 years ago.

In 1998, we established research quadrats for the study of biomass and community structure. We moved on to ecological restoration in 2004 and established research transects. The last field survey of all the communities was conducted in May 2005. We established seven transects across the whole land-sea interface zone for each ecosystem in the study area, and various numbers of $10 \mathrm{~m} \times 10 \mathrm{~m}$ quadrats were placed along each transect depending on the length of the transects (number of quadrats: barren sites, 3; native plantation, 4; natural site, 3; exotic species plantation 4-year, 3; exotic species plantation 5-year, 7; exotic species plantation 8-year, 8; exotic species plantation 10-year, 3). For each of the four types of ecosystems (i.e. natural mangrove forest, barren site, native species mangrove plantation, and $S$. apetala plantations) and the four age classes (4-, 5-, 8- and 10-year) of $S$. apetala plantation, only three quadrats were selected for further analysis. The number of species, plant height, diameter at breast height (DBH - trees only), basal diameter, crown size, 8-year plantation, 5 4-year plantation, 6 artificial native mangrove plantation, 7 10-year plantation

and growth status (alive or dead) of each individual were recorded. Density, basal area and absolute frequency, the important value (IV), number of species, and Shannon-Weiner (SW) index were computed (Snedaker 1984; Krebs 1985).

Three $20-\mathrm{cm}$ soil cores were taken from each of the $10 \mathrm{~m} \times 10 \mathrm{~m}$ quadrats randomly to form a mixed sample, using a $3.7-\mathrm{cm}$ diameter coring tube. Three replicates were taken from each quadrat at low tide. Water content was measured by the weight loss method. Salinity was measured using an optical refractometer, and temperature and $\mathrm{pH}$ were measured using an auto-thermometer and a $\mathrm{pH}$ meter, respectively. Samples were oven-dried at $80^{\circ} \mathrm{C}$ for about 3 days until constant dry weight was obtained, then stored for analysis. Analysis of organic matter, total $\mathrm{N}$, total P, and clay followed Wartel et al. 1995 (see also Arnold 1986; Robert et al. 1997; Bosire et al. 2003).

The sediment characteristics data were assessed by a Tukey-test after one-way ANOVA $(P<0.05)$ to indicate significant differences. All statistics were analysed by SPSS11.5 software.

\section{Results}

Physical conditions

Among the ecosystems studied, the barren sites showed the harshest physical conditions for plant growth, i.e. 
lowest organic matter, total $\mathrm{N}$, and total $\mathrm{P}$ content, but highest proportion of sand compared to other sites. In contrast, the natural mangrove forests showed the best conditions as indicated by the high content of organic matter, total $\mathrm{N}$ and clay. In the planted stands of exotic species, all conditions improved with planting age, i.e. salinity, organic matter content, and proportion of clay all increased with planting age while $\mathrm{pH}$ declined, and there was no clear trend in total $\mathrm{N}$ and $\mathrm{P}$. By the 10th year, most conditions in the exotic plantations had become similar to those found in natural mangrove. This suggested that there were significant effects of mangrove plantation on soil physical and chemical properties during the course of recovery (Table 1). The improvement in soil physical and chemical properties in plantations facilitated the invasion of native mangrove species. Regression analysis showed that the organic matter content of plantations could reach that of natural mangrove communities in about 14 years (Fig. 2).

\section{Community structure}

In the past 10 years, no plants (including mangrove species) were found in the barren sites (Table 2). Pure stands of $R$. stylosa and $K$. candel were planted separately but neither species colonised or invaded each other's stands, although in natural mangroves $A$. marina, K. candel, Aegiceras corniculatum (Linn.) Blanco and $R$. stylosa are the dominant species.

In the $S$. apetala plantations, the planted species was still the single dominant species after 10 years, and both species richness and density of mangroves were lower than that in natural mangrove communities, although most element conditions were already restored.

\section{Recruitment}

We did not observe any native mangrove species seedlings in 1-3 year $S$. apetala plantations. The plant height, DBH and cover of $S$. apetala all increased with planting age. However, native species such as $K$. candel, $R$. stylosa, A. marina, and A. corniculatum started to colonise in 4-year $S$. apetala plantations and more species and individuals were observed in 4-5 year plantations. The monoculture native species mangrove plantations grew slowly and no natural regeneration or re-colonisation was observed. Comparatively, the species richness was higher and there were rapid recruitments, with most of the new seedlings being native species in natural forests. The 5-year plantation ranked second in terms of seedling density (both native species and exotic species). The 8-year plantation ranked the third in recruits but the planted species had no new seedlings, and all recruited seedlings belonged to one recolonised native species. The 10 -year plantation had two species (one planted and one native) and $52.4 \%$ of the seedlings belonged to native species (Table 3 ). The

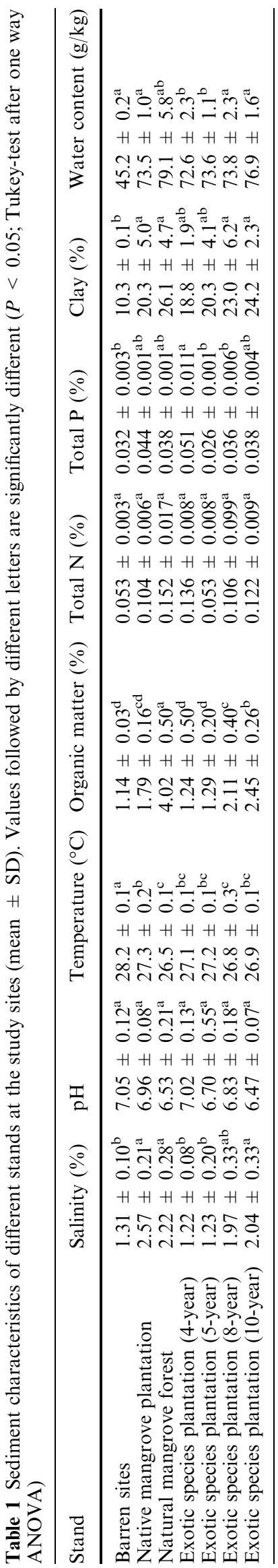


regeneration of mangrove was determined by seed source and seedling quantity. Table 3 also indicated that $S$. apetala could not regenerate in its plantation. Some

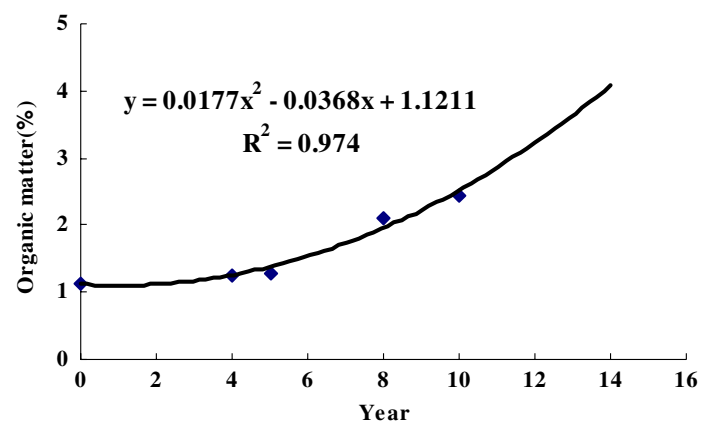

Fig. 2 Relationship between age of plantation and soil organic matter content native mangrove species could invade the 4-5-year-old $S$. apetala plantations, but those native species disappeared after 10 years in plantation. In addition, most recolonisation occurred in quadrats far away from seawater.

\section{Discussion}

Long time periods may be required for barren lands to develop vegetation in extremely degraded environments without human assistance. We found no natural re-colonisation in barren sites after 20 years but some species had recruited into several $S$. apetala plantations after 4 years. These results indicate that clearing mangroves may provide an obstacle to natural regeneration, whereas $S$. apetala plantations can greatly modify the

Table 2 Community characteristics of the study sites with different stands. $I V$ Important value, SWI Shannon-Weiner index

\begin{tabular}{|c|c|c|c|c|c|c|c|}
\hline Stand & Characteristic & $\begin{array}{l}\text { Avicennia } \\
\text { marina }\end{array}$ & $\begin{array}{l}\text { Rhizophora } \\
\text { stylosa }\end{array}$ & $\begin{array}{l}\text { Kandelia } \\
\text { candel }\end{array}$ & $\begin{array}{l}\text { Aegiceras } \\
\text { corniculatum }\end{array}$ & $\begin{array}{l}\text { Sonneratia } \\
\text { apetala }\end{array}$ & Total \\
\hline Native mangrove plantation & $\begin{array}{l}\text { Density }(\mathrm{N} / \mathrm{ha})^{\mathrm{a}} \\
\text { Basal area }\left(\mathrm{m}^{2} / \text { ha }\right) \\
\text { Frequency } \\
\text { IV } \\
\text { Mean stand height (m) } \\
\text { Number of species } \\
\text { SWI }\end{array}$ & & $\begin{array}{c}7,333 \\
0.026 \\
0.3 \\
0.33 \\
1.9\end{array}$ & $\begin{array}{c}5,767 \\
0.239 \\
0.7 \\
0.67 \\
0.9\end{array}$ & & & $\begin{array}{r}13,100 \\
0.265 \\
\\
1.00 \\
1.55 \\
2 \\
0.47\end{array}$ \\
\hline Natural mangrove forest & $\begin{array}{l}\text { Density }(\mathrm{N} / \mathrm{ha})^{\mathrm{a}} \\
\text { Basal area }\left(\mathrm{m}^{2} / \mathrm{ha}\right) \\
\text { Frequency } \\
\text { IV } \\
\text { Mean stand height }(\mathrm{m}) \\
\text { No of species } \\
\text { SWI }\end{array}$ & $\begin{array}{c}13,133 \\
1.103 \\
1.0 \\
0.48 \\
1.21\end{array}$ & $\begin{array}{c}1,233 \\
0.166 \\
1.0 \\
0.13 \\
1.10\end{array}$ & $\begin{array}{c}7,967 \\
0.236 \\
1.0 \\
0.23 \\
1.70\end{array}$ & $\begin{array}{c}2,400 \\
0.091 \\
1.0 \\
0.15 \\
1.60\end{array}$ & & $\begin{array}{r}24,733 \\
1.596 \\
\\
1.00 \\
1.62 \\
5 \\
1.38\end{array}$ \\
\hline $\begin{array}{l}\text { Exotic species plantation } \\
\text { (4-year) }\end{array}$ & $\begin{array}{l}\text { Density }(\mathrm{N} / \mathrm{ha})^{\mathrm{a}} \\
\text { Basal area }\left(\mathrm{m}^{2} / \mathrm{ha}\right) \\
\text { Frequency } \\
\text { IV } \\
\text { Mean stand height }(\mathrm{m}) \\
\text { No of species } \\
\text { SWI }\end{array}$ & $\begin{array}{c}367 \\
\quad 0.064 \\
0.7 \\
0.10 \\
1.40\end{array}$ & $\begin{array}{c}2,267 \\
0.137 \\
1.0 \\
0.31 \\
1.31\end{array}$ & $\begin{array}{c}233 \\
0.100 \\
1.0 \\
0.12 \\
1.00\end{array}$ & & $\begin{array}{c}700 \\
\quad 9.888 \\
1.0 \\
0.48 \\
3.5\end{array}$ & $\begin{array}{r}3,567 \\
10.189 \\
\\
1.00 \\
3.32 \\
4 \\
1.47\end{array}$ \\
\hline $\begin{array}{l}\text { Exotic species plantation } \\
\text { (5-year) }\end{array}$ & $\begin{array}{l}\text { Density }(\mathrm{N} / \mathrm{ha})^{\mathrm{a}} \\
\text { Basal area }\left(\mathrm{m}^{2} / \mathrm{ha}\right) \\
\text { Frequency } \\
\text { IV } \\
\text { Mean stand height }(\mathrm{m}) \\
\text { Number of species } \\
\text { SWI }\end{array}$ & $\begin{array}{c}6,533 \\
0.906 \\
1.0 \\
0.36 \\
0.9\end{array}$ & $\begin{array}{l}200 \\
\quad 0.068 \\
0.7 \\
0.07 \\
0.72\end{array}$ & $\begin{array}{c}1,867 \\
0.780 \\
1.0 \\
0.20 \\
0.71\end{array}$ & $\begin{array}{l}200 \\
\quad 0.003 \\
0.3 \\
0.03 \\
0.50\end{array}$ & $\begin{array}{c}1,467 \\
3.005 \\
1.0 \\
0.34 \\
4.35\end{array}$ & $\begin{array}{r}10,267 \\
4.760 \\
\\
1.00 \\
4.35 \\
5 \\
1.40\end{array}$ \\
\hline $\begin{array}{l}\text { Exotic species plantation } \\
\text { (8-year) }\end{array}$ & $\begin{array}{l}\text { Density }(\mathrm{N} / \mathrm{ha})^{\mathrm{a}} \\
\text { Basal area }\left(\mathrm{m}^{2} / \text { ha }\right) \\
\text { Frequency } \\
\text { IV } \\
\text { Mean stand height }(\mathrm{m}) \\
\text { Number of species } \\
\text { SWI }\end{array}$ & & & $\begin{array}{c}11,833 \\
0.504 \\
1.0 \\
0.54 \\
1.00\end{array}$ & & $\begin{array}{c}1,567 \\
1.733 \\
1.0 \\
0.46 \\
7.50\end{array}$ & $\begin{array}{r}13,400 \\
2.237 \\
\\
1.00 \\
7.50 \\
2 \\
0.77\end{array}$ \\
\hline $\begin{array}{l}\text { Exotic species plantation } \\
\text { (10-year) }\end{array}$ & $\begin{array}{l}\text { Density }(\mathrm{N} / \mathrm{ha})^{\mathrm{a}} \\
\text { Basal area }\left(\mathrm{m}^{2} / \mathrm{ha}\right) \\
\text { Frequency } \\
\text { IV } \\
\text { Mean stand height }(\mathrm{m}) \\
\text { Number of species } \\
\text { SWI }\end{array}$ & & & & & $\begin{array}{c}1,067 \\
7.005 \\
1.0 \\
1.00 \\
12.2\end{array}$ & $\begin{array}{c}1,067 \\
7.005 \\
1.0 \\
1.00 \\
12.2 \\
1 \\
0.00\end{array}$ \\
\hline
\end{tabular}

\footnotetext{
${ }^{a}$ Not including seedlings
} 
Table 3 Seedling density (individuals/ha) of mangrove trees in quadrats with different stands

\begin{tabular}{|c|c|c|c|c|c|c|c|c|}
\hline \multicolumn{2}{|l|}{ Stand } & S. apetala & K. candel & R. stylosa & $\begin{array}{l}\text { Avicennia } \\
\text { marina }\end{array}$ & $\begin{array}{l}\text { Aegiceras } \\
\text { corniculatum }\end{array}$ & $\begin{array}{l}\text { Acanthus } \\
\text { ilicifolius }\end{array}$ & Total \\
\hline \multicolumn{2}{|l|}{ Barren sites } & 0 & 0 & 0 & 0 & 0 & 0 & 0 \\
\hline \multicolumn{2}{|c|}{$\begin{array}{l}\text { Native plantation } \\
\text { Natural site }\end{array}$} & 0 & 0 & 0 & 0 & 0 & 0 & 0 \\
\hline \multicolumn{2}{|c|}{ Natural site } & 0 & 5,333 & 667 & 2,333 & 930 & 0 & 9,263 \\
\hline Exotic & 4-year & 25 & 175 & 1,775 & 550 & 0 & 0 & 2,525 \\
\hline Species & 5-year & 200 & 2,057 & 87 & 5,586 & 86 & 0 & 8,016 \\
\hline \multirow[t]{2}{*}{ Plantation } & 8-year & 0 & 6,950 & 0 & 0 & 0 & 0 & 6,950 \\
\hline & 10 -year & 333 & 0 & 0 & 0 & 0 & 367 & 700 \\
\hline
\end{tabular}

site conditions in a way that facilitates the survival and establishment of the propagules of native species. These results are somewhat similar to those of other studies (Field 1999; Ellison 2000; Bosire et al. 2003; Liang et al. 2005). Compared with barren sites, salinity and interstitial water temperature were lower, and the organic matter content was higher, in most restored and natural sites. The possible causes include shading, aerial roots breaking waves, hydrological dynamic changes, and plant nutrition cycle.

Our study suggests that natural regeneration may not occur, and that artificial regeneration (i.e. plantation) of native mangroves may not be effective, in seriously degraded mangrove ecosystems. In severely degraded ecosystems, regeneration of mangrove vegetation might not occur without human intervention because natural regeneration replies on naturally occurring propagules of mangroves. Natural colonisation rates vary among sites and mangrove species, but it is still the first choice for a restoration program. After the physical environment is modified, artificial regeneration involves planting of propagules (seeds) or seedlings in severely degraded region where there are insufficient seeds or natural regeneration pathways.

Our results indicated that the growth performance of the exotic mangrove species, S. apetala, was better than that of some native species such as $R$. stylosa and $K$. candel in the first 10 years after plantation. Due to its fast growth and high adaptability, $S$. apetala is now also being introduced to Fujian Province $\left(108^{\circ} 30^{\prime} \mathrm{E}\right.$ and $24^{\circ} 23^{\prime} \mathrm{N}$ ). Local governments even intended to widely expand distribution of this species in China's southeast coasts. However, restorationists are beginning to worry about its invasive potential in native mangrove stands. Therefore, it is necessary to assess the ecological risk of such species introduction at a broader (regional) scale (Zan et al. 2003). Our study has shown that S. apetala plantations facilitated the re-colonisation of native mangrove species in early stages, where it behaves as a nurse plant. However, its high self-regeneration ability in the community prevents the natural succession of the native community. Therefore, we might use $S$. apetala as a pioneer species to improve habitats and to facilitate re-colonisation of native mangrove species. As soon as the deposition conditions are restored, ornative species are suppressed by the exotic species, we should then artificially remove $S$. apetala so that native species can dominate the community. Thus, the restoration could then follow ideal natural self-organisation processes.

It is clear that monitoring of the plantations for only 10 years is still not long enough to examine whether recolonised native species can eventually take over or outcompete the planted exotic species without human intervention, since the deposition conditions have not yet been fully restored. We suggest removing planted exotic mangrove species about 5 years later to ensure the performance of native species, but the optimal time for this artificial removal needs further investigation. Further monitoring and comparative studies of different remediation treatments would be useful. It is also clear that, to make sustainable use of mangrove in South China, it is necessary to protect all the existing mangrove wetlands in situ by setting up natural reserves and excluding further anthropogenic destruction, and developing a solid scientific program for restoration. Furthermore, carefully designed broad-scale monitoring and enhanced education programs are critically required to effectively protect the limited resources of mangrove ecosystems.

Acknowledgements We thank Drs. Rui-Jiang Wang and Hong-Fu Wan of the South China Botanical Garden and all staff of the Administration of Zhanjiang Mangrove National Natural Reserve for field assistance during the study. We also thank anonymous reviewers for their valuable comments on the early version of the manuscript. This project was supported by the Knowledge Innovation Program of the Chinese Academy of Sciences (KSCX2-SW132), Natural Science Foundation of China (30670370, 30600072) and the Guangdong Sci-Tech Planning Project (2005B60301001).

\section{References}

Arnold K (1986) Methods of soil analysis. Part I. Physical and mineralogical methods, 2nd edn. Soil Science Society of America, Madison, WI

Bosire JO, Dahdouh-Guebas F, Kairo JG, Koedam N (2003) colonisation of non-planted mangrove species into restored mangrove stands in Gazi Bay, Kenya. Aquat Bot 76:267-279

Chen YJ, Liao BW, Zheng SF et al (2004) Dynamics and speciesdiversities of artifical Sonneratia apetala, Sonneratia caseolaris and Kandelia candel communities. Chin J Appl Ecol 15:924-928

Ellison AM (2000) Mangrove restoration: do we know enough? Restoration Ecol 8:219-229

FAO (1994) Mangrove forest management guideline. FAO, Rome 
Field CD (1999) Remediation of mangrove ecosystems: an overview. Mar Pollut Bull 37:383-392

Han WD, Gao XM, Teunissen E (2001) Study on Sonneratia apetala productivity in restored forests in Leizhou Peninsula, China. J For Res 12:229-234

Han WD, Gao XM, Lu CY, Lin P (2003) Mangrove flora and associations of Leizhou Peninsula. Guihaia 23:127-132

Zan QJ, Wang BS, Wang YJ, Ming-Guang L (2003) Ecological assessment on the introduced Sonneratia caseolaris and $S$. apetala at the Mangrove Forest of Shenzhen Bay. China. Acta Bot Sin 45:604-612

Kathiresan K, Bingham BL (2001) Biology of mangroves and mangrove ecosystems. Adv Mar Biol 40:81-251

Kovacs JM (1999) Assessing mangrove use at the local scale. Landsc Urban Plan 43:201-208

Krebs CJ (1985) Ecology: the experimental analysis of distribution and abundance, 2rd edn. Harper \& Row, New York

Lewis RR III (2005) Ecological engineering for successful management and restoration of mangrove forests. Ecol Eng 24:403418

Li ZQ (2003) Orientation and management strategy of mangrove forest in the forestry development of Guangdong. Prot For Sci Technol 56:36-38

Li Y, Zhen DZ, Chen HX et al (1998) Preliminary study on introduction of mangrove Sonneratia apetala Buch-Ham. For Res 11:39-44

Liang SC, Liang MZ, Wu YL, Zan QJ, Wang YJ, Xie Q (2005) Analysis of the spatial structure of natural Sonneratia caseolaris + S. apetala forest in Futian, Shenzhen. Guihaia 25:393398

Liao BW, Zheng SF, Chen YJ et al (2004) Biological characteristics and ecological adaptability for non-indigenous mangrove species Sonneratia apetala. Chin J Ecol 23:10-15

Liao BW, Li M, Zheng ZF et al (2005) Niches of several mangrove species in Dongzhai harbor of Hainan island. Chin J Appl Ecol $16: 430-407$
Lin ZL (1999) Current situation and conservation of mangrove forest in Guangdong. Ocean Inf 6:25-27

Lin ZD, Liu HM (2003) Protection and management countermeasures for mangrove resource in Guangdong province. Central South For Invent Plan 22:35-38

Lin KY, Zhang QM, Ren H (2006) Mangrove resource and sustainable development at Zhanjiang. Ecol Sci 23:23-29

Lugo AE (1999) Mangrove forests: a tough system to invade but an easy one to rehabilitate. Mar Pollut Bull 37:427-430

Macintosh DJ, Ashton EC, Havanon S (2002) Mangrove remediation and intertidal biodiversity: a study in the Ranong mangrove ecosystem, Thailand. Estuar Coast Shelf Sci 55:331-345

Robert L, Morlang A, Gorman L (1997) Monitoring the coastal environment. Part II. Sediment sampling and geotechnical methods. J Coast Res 13:308-330

Snedaker SC (ed) (1984) The mangrove ecosystem: research methods. UNESCO, Paris

Wang BS, Liao BW, Wang YJ et al (2002) Mangrove forest ecosystem and its sustainable development in Shenzhen Bay. Science, Beijing

Wartel S, Barusseau J, Cornand L (1995) Improvement of grain size analyzes using the automated SEDIGRAPH 5100. Document 80. KBIN, Brussels, Belgium

Wu ZH, Cai JX, Ye XB (2000) Analysis on effects of introduction and popularization of Sonneratia apetala. Guangdong For Sci Technol 16:6-10

Zan QJ, Wang YJ, Liao BW et al (2001a) The structure of Sonneratia apetala $+S$. caseolaris-Kandelia candel mangrove plantations of Futian, Shenzhen. For Res 14:610-615

Zan QJ, Wang YJ, Wang BS (2001b) The ecological effects of Sonneratia apetala $+S$. caseolaris mangrove plantations of Futian, Shenzhen. Acta Sci Natl Univ Sunyatseni 40:72-76

Zedler JB (ed) (2000) Handbook for restoring tidal wetlands. CRC, London 